\title{
Konstruksi Ujaran Kebencian Melalui Status Media Sosial
}

\author{
Tangguh Okta Wibowo* \\ Universitas Gadjah Mada \\ Email: tangguh.o.w@ugm.ac.id* \\ *corresponding author
}

\author{
Keywords: \\ Social media \\ Facebook and Twitter Status \\ Hate speech \\ UU ITE
}

\begin{abstract}
This study explores the complexity of dilemma experienced by social media users, due to the presence of the Law number 11 of 2008 on Electronic Information and Transactions ITE) (especially article 27 paragraph 3) which ensnare many victims. In the last eight years (2008-2016), there were 141 cases of the reported victims because of article 27 paragraph 3 on suspicion of hate speech (recorded by Safenet Voice). This study focuses on the practice of social media users (especially Facebook and Twitter) as a medium -when users express more easier about their certain emotions- to express various opinions. Next, this article discuss the problems about privacy and embodiment using social media.
\end{abstract}

\begin{abstract}
ABSTRAK
Studi ini mengeksplorasi kompleksitas pergolakan yang dialami pengguna media sosial, karena kehadiran Undang-Undang No. 11 tahun 2008 tentang Informasi dan Transaksi Elektronik (UU ITE) (khususnya pasal 27 ayat 3) yang menjerat banyak korban. Sejak delapan tahun terakhir (2008-2016), korban pelaporan ke pihak kepolisian sekitar 141 kasus dengan pasal 27 ayat 3 ini atas dugaan ujaran kebencian (tercatat oleh Safenet Voice). Studi ini fokus terhadap praktik pengguna media sosial (khususnya Facebook dan Twitter), sebagai media - ketika pengguna lebih mudah untuk mencurahkan emosi tertentu - untuk mengekspresikan berbagai pendapat. Selanjutnya tulisan ini membahas permasalahan privasi dan penubuhan dalam bermedia sosial.
\end{abstract}

Copyright (C) 2018 Channel Jurnal Komunikasi. All right reserved.

Kata kunci:

Media sosial

Status Facebook dan Twitter

Ujaran kebencian

UU ITE

\section{PENDAHULUAN}

Survei yang dilakukan tim BCG terhadap konsumsi digital di negara pengguna internet terbanyak di dunia, laporannya menunjukkan bahwa pengguna internet di Indonesia (peringkat keenam dunia) melonjak dari 20 juta (2006) menjadi 31 juta (2009) dan 94 juta (2015) (BCG Report, 2015). Diperkirakan di tahun 2017 terjadi pelonjakan 112 juta orang dan mengalahkan Jepang yang berada di peringkat ke-5 dunia (posisi Indonesia sekarang sebagai peringkat ke-6 pengguna internet dunia) (Kominfo, 2014).

Perilaku online orang Indonesia kebanyakan menggunakan fasilitas yang ada di smartphone untuk bermedia sosial (BCG report, 2015:10) dengan pengguna aktif di tahun 2016 sebanyak 79 juta (Balea, 2016) dan 70\% mengakses internet melalui smartphone (sisanya mengakses melalui laptop, PC, dan tablet). Hal ini dapat digambarkan lambatnya pertumbuhan PC (perangkat komputer) di Indonesia (2006-2009-2015 meningkat dari 6 juta, 11 juta, sampai 38 juta), tidak terlalu signifikan dibandingkan dengan pertumbuhan penetrasi smartphone yang melonjak tajam (2006-2009-2015 meningkat dari 66 juta, 166 juta, sampai 274 juta) (BCG Report, 2015). Di Indonesia sendiri juga terdapat beberapa media sosial yang populer dan dilaporkan oleh TechinAsia jika penggunaan media sosial yang berada dalam posisi teratas di Indonesia adalah Facebook dan Twitter (Balea, 2016). 
Data di atas menunjukkan karakteristik pengguna internet di Indonesia yang gemar mengakses smartphone untuk keperluan bermedia sosial, terutama Facebook dan Twitter. Tetapi di sisi lain, data ini juga tidak dapat dielakkan jika di Indonesia mengalami pergolakan yang ramai sejak hadirnya Undang-Undang No. 11 tahun 2008 tentang Informasi dan Transaksi Elektronik (selanjutnya disebut sebagai UU ITE) terkait budaya dunia siber (cyberculture) yang tidak bisa dilepaskan dari teknologi internet.

Tercatat oleh Safenet Voice (Southeast Asia Freedom of Expression Network), sebagai gerakan yang mempromosikan kebebasan berbicara di Asia Tenggara, dari tahun 2008 hingga 2016 tercatat 179 kasus terkait UU ITE. Pasal yang sering digunakan terutamanya pasal 27 dan 28. Dikutip oleh CNN Indonesia, sebanyak 79,3 persen perkara ITE menggunakan pasal 27 ayat 3 mengenai pencemaran nama baik (Sugiharto, 2016).

Artikel ini merupakan studi kasus yang menggambarkan bagaimana internet memberikan kebebasan berpendapat, akan tetapi juga menjadi sebuah ancaman bagi pengguna dalam bermedia sosial yang bisa saja terjerat oleh UU ITE. Pasal yang akan disoroti di artikel ini adalah pasal 27 ayat 3, akan tetapi bukan untuk dieksplorasi dari sisi hukum, melainkan sosial-budaya penggunanya di dunia siber.

Studi ini bertujuan untuk mengeksplorasi pergolakan bermedia sosial dan janjinya di dunia siber yang memberikan kebebasan berpendapat atau juga batasan dari praktik tersebut, hingga kepada penubuhan (embodiment) mengingat banyak korban yang telah dilaporkan kepada pihak kepolisian atas tuduhan pencemaran nama baik. Bisa dikatakan jika profil online di media sosial, tidak bisa lepas begitu saja untuk tidak menjadi korban 'pembungkaman' oleh pihak-pihak tertentu, sehingga menimbulkan perlawanan/ resistansi berbagai macam partisipasi online untuk menentang UU ITE terutama pasal 27 ayat 3 (pencemaran nama baik).

Argumen yang coba dibangun dalam tulisan ini adalah meskipun bermedia sosial menawarkan kebebasan dalam berpendapat, tetapi hal tersebut tidak bisa lepas dari restriksi yang ada, terutama kepada pihak yang merasa tidak terima atau tersinggung dan melaporkan kepada pihak berwajib atas tuduhan pencemaran nama baik karena status media sosial orang lain yang menyangkut pelapor. Untuk mengejawantahkan pergolakan di atas, tulisan ini mencoba untuk mengeksplorasi berbagai permasalahan yang terjadi berkaitan dengan kasus pengguna media sosial terjerat pelaporan UU ITE dan limitasi kajian pada kasus yang terkena pasal 27 ayat 3.

\section{METODE PENELITIAN}

Merujuk pada etnografi baru yang ditawarkan Paula Saukko (2003:94) bahwa sebuah penelitian bukan bertujuan menetapkan konsensus. Akan tetapi sebuah penelitian yang menghadirkan beragam pengalaman untuk menyoroti kompleksitas yang bisa saja bersifat keduanya, yaitu menguasakan (empowerment) atau pun melemahkan (disempowerment) elemen dari wacana. Sebagai metode, pergolakan bermedia sosial dihadirkan untuk dianalisis secara vertikal, kemudian studi ini mencoba mengeksplorasi secara horizontal perkelindanan dengan pengalaman kehidupan riil pengguna dalam konteks bermedia sosial yang bisa saja menjadikan pengguna sebagai "calon korban" pelaporan oleh pihak tertentu menggunakan UU ITE pasal 27 ayat 3.

Penelitian tidak akan pernah sempurna, oleh karena itu studi ini mengadopsi kerangka metodologis Saukko yang tidak hanya berhenti pada teks dan konteks, akan tetapi dikaitkan dengan lived experiences (pengalaman kehidupan riil). Karena dengan refleksi diri, pengalaman empiris seseorang bisa sangat berbeda dengan lainnya dan semua ini di luar pengalaman dari seorang peneliti. Sehingga studi ini juga mengadopsi suara dari berbagai pengalaman kehidupan riil dan mengedepankan polivokalitas untuk dibahas secara kritis dalam artikel ini.

Tulisan ini mengangkat beberapa kasus terkait permasalahan ujaran kebencian yang sempat menjadi perbincangan hangat di dunia maya dan berimbas kepada pelaporan seseorang karena pendapatnya tersebut. Lebih lanjut, saya juga telah menwawancarai secara mendalam dua pengguna media sosial dengan berbagai latar belakang berbeda yang dihadirkan di artikel ini (dengan nama samaran untuk menjaga privasi mereka), yaitu Jono dan Ananda.

\section{DISKUSI}

\section{a. Menyoal Privasi Bermedia Sosial}

Secara umum, masyarakat sekarang ini bisa dikatakan 'dimanjakan' oleh internet melalui teknologi Web 2.0 yang bisa dimanfaatkan untuk berkomunikasi secara individu atau jejaring. Media sosial, seperti Facebook dan Twitter, terbukti sangat berguna bagi pengguna yang ingin terlibat dalam sebuah debat, untuk memobilisasi, dan mengorganisasi atas tujuan politis. Internet menjadi institusi sentral dari public sphere (ruang publik) bagi masyarakat yang fokus pada berita dan berdiskusi politik (Dahlgren, 2013:401).

Argumen yang terdengar emansipatoris, yaitu ketika media sosial memiliki peran menghubungkan masyarakat dalam jejaringnya. Akan tetapi jika menilik fasilitas yang dijanjikan, praktiknya di Indonesia tidak lepas dengan adanya limitasi dari regulasi yang diterapkan. Melalui Undang-Undang No. 11 tahun 2008 tentang Informasi dan Transaksi Elektronik No. 11 (UU ITE), beberapa pasalnya ampuh untuk digunakan pihak yang tersinggung oleh status orang lain melaporkan kepada pihak berwajib. Sesuai limitasi studi ini fokus pada kasus yang terkena pasal 27 Ayat 3, berbunyi: 
"Setiap orang dengan sengaja dan tanpa hak mendistribusikan dan/atau mentransmisikan dan/atau membuat dapat diaksesnya Informasi Elektronik dan/atau Dokumen Elektronik yang memiliki muatan penghinaan dan/atau pencemaran nama baik."

Dikutip dari artikel CNN Indonesia (Sugiharto, 2016) menyebutkan jika Pasal 27 ayat 3 dalam UU ITE ini dianggap sebagai pasal karet, yaitu dianggap menjadi 'alat' pamungkas untuk menjerat suatu perkara hukum berkaitan dengan ITE.

Tanggal 9 Juni 2008, korban pertama kali dari pasal pencemaran nama baik cerita dari kasus Prita Mulyasari. Dikutip dari berita tekno kompas (Widiantoro, 2015), Prita Mulyasari bermula pada 15 Agustus 2008, ia mengeluhkan pelayanan dari RS Omni Internasional melalui e-mail kepada teman-temannya, dan kemudian tersebar atau viral ke sejumlah mailing list di internet. Pihak RS mengambil langkah hukum. Prita terjerat pasal 310 dan 311 KUHP tentang pencemaran nama baik serta pasal 27 ayat (3) Undang-undang Informasi dan Transaksi Elektronik dengan ancaman hukuman selama enam tahun penjara. Ia terjerat pasal 27 ayat 3 UU ITE sebagai bukti adanya unsur informasi elektronik, dan diperkuat 310 dan 311 KUHP. Setelah peninjauan kembali oleh MA, tanggal 17 September 2012 Prita akhirnya bebas. Dari total 179 kasus, sebagian besar kasus dilaporkan melalui status Facebook (101 kasus) dan Twitter (22) (Safenet Voice, 2017).

Kasus berikutnya yang sempat booming, yaitu Ervani Emy Handayani. Di tahun 2014, dia mencurahkan isi hatinya melalui status Facebook yang berisi kekesalan terhadap nama atasan (Ayas) dan supervisor yang memutasi suaminya ke kantor cabang lain. Ervani menyebutnya mereka tidak layak menjadi pemimpin di Jolie Jogja Jewellery, dan di status Facebooknya dia menulis dengan kritikan “...Banyak yang lebay dan masih labil seperti anak kecil!” Kemudian Ayas melaporkan Ervani ke pihak berwajib atas tuduhan pencemaran nama baik dan terjerat pasal 27 ayat 3, pasal 310 KUHP, dan pasal 311 KUHP (Yanuar, 2015).

Selanjutnya, kasus status twitter Benny Handoko yang dijerat dengan pasal 27 ayat 3 atas pencemaran nama baik dengan vonis hukuman 6 bulan penjara dengan 1 tahun masa percobaan. Di status Twitternya, Benny menyebut mantan anggota DPR Muhammad Misbakhun dengan sebutan "Perampok Century." Karena ciutannya tersebut, Misbakhun melaporkannya ke pihak kepolisian (Mozes, 2014).

Tiga kasus di atas adalah segelintir dari 179 kasus yang dilaporkan melalui status Facebook dan Twitter. Akan tetapi persoalan yang terpenting di kasus tersebut adalah privasi di dunia siber. Privasi misalnya, antara Ervani dan Ayas tidak berteman di Facebook, begitu pula Benny tidak saling mengikuti akun Misbakhun atau ibaratnya mereka tidak dalam satu lingkungan sosial pertemanan. Karena masyarakat sekarang tidak lagi sebagai audiens, tetapi sebagai 'produser' aktif (Dahlgren, 2013:401) atau sekarang disebut sebagai prosumsi (produksi-dan-konsumsi) (Lihat lebih lanjut istilah prosumsi baca Toffler, 1980 dan Ritzer, 2013).

Melalui fitur Web 2.0 akan UGC (User-Generated Content), sebagai pengguna, individu memiliki keleluasaan untuk membuat akun media sosial yang mewakili atau merepresentasikan dirinya sebagai identitas diri secara online. Pengguna kemudian 'mengonsumsi' apa yang dia rasakan di kesehariannya baik secara online atau offline. Mengingat karakter kebanyakan netizen di Indonesia, dikutip dari penelitian Digital GFK Asia yang menyatakan jika pengguna media sosial di Indonesia rata-rata menghabiskan 5,5 jam sehari (Perempuan 5,6 jam dan pria 5,4 jam) (Rakhmansyah, 2017). Lalu melalui akun media sosialnya, user dapat mengekspresikan pendapatnya (free speech) melalui status Facebook atau Twitter. Singkatnya, jika ada pihak tertentu yang 'tidak berada dalam lingkungan sosial pertemanannya' merasa tersinggung atau ada pihak yang sengaja men-screenshot (memfoto status) dan melaporkan kepada pihak yang dimaksud dalam status tersebut. Inilah persoalan privasi mulai muncul. Dapat dikatakan jika pihak lain yang berasal dari 'luar grup pertemanan' menjadi pihak yang 'berbahaya,' karena bisa saja pihak ini menginterpretasikan lain dan merasa tersinggung dan merasa disudutkan (seperti kasus Benny, di mana Misbakhun merasa tersudutkan dan difitnah). Pendapat yang menarik untuk menguraikan persoalan privasi ini:

“Jika kita bisa menciptakan sebuah mesin yang berisi apa yang kita pikirkan, lalu mesin itu adalah kita sendiri. Sekarang, mesin tersebut bisa hidup selamanya. Bahkan jika tidak selamanya, ada orang lain yang mengambilnya dan membuat backup (salinan arsip), kemudian dibuka melalui mesin lain akibat mesin sebelumnya rusak. (Kutipan dari Jeremy Rifkin, Biosphere Politics: A New Consciousness for a New Century (New York: Crown, 1991; Morse, 2006).",

Disinilah, ketika media sosial merangsang untuk memediasi 'mesin' tersebut, melalui status Facebook atau Twitter, semua orang bisa mengakses dan mengetahui apa yang kita pikirkan. Seperti yang McLuhan (1964) utarakan bahwa suatu medium bisa menjadi medium yang lain. Dengan mudah status orang lain untuk kita copy atau screenshot untuk direproduksi dan dibagi di status milik kita, bahkan status kita (bisa berupa hasil dari reproduksi) dapat disebarkan kembali oleh orang lain dan hadir dimana-mana. Salah satu elemen dari hadir dimana-mana (ubiquity) adalah pengguna bisa mengakses informasi kapan pun, begitupula bisa diakses oleh pengguna lain (Calka, 2015:17). 
Masih ada keterkaitan dengan kutipan Jeremy Rifkin yang mengilustrasikan kita sebagai sebuah mesin; persoalan yang kedua adalah penubuhan (embodiment) di dunia siber. Bagaimana melalui akun media sosial —lebih detailnya melalui status media sosial, seseorang bisa dilaporkan di dunia 'nyata' dan ia wajib untuk menghadapi persidangan jika unsur-unsur dalam UU ITE terpenuhi. Hal ini merujuk pada persoalan internet telah mengubah akun media sosial menjadi terkoneksi atau menubuh pada sebuah entitas di dunia nyata.

\title{
b. Penubuhan dalam Bermedia Sosial
}

Merujuk pada wawancara dengan Jono (seorang jurnalis), dia menceritakan kasus yang belum terekspos oleh media, yaitu kasus seorang mahasiswa berinisial AY, dari Universitas Swasta dari kota Yogyakarta. Hasil wawancara saya dengan Jono:

\begin{abstract}
"Saat saya mewawancarai AY, dia tidak mau direkam, difoto, dan divideo. Dia komplain ada fasilitas yang rusak di kosnya. Setiap komplain kepada pemilik kos, tidak mendapat tanggapan. Akhirnya dia merasa kesal dan memfoto fasilitas kos yang rusak tersebut di status Facebook miliknya. Kemudian pemilik kos mengetahuinya (entah dari mana mengetahuinya, yang jelas tidak berteman di Facebooknya). Kemudian pemilik kos ini melaporkan status tersebut atas pencemaran nama baik. Polisi memediasi permasalahan ini. Pemilik kos bersedia mencabut laporan kalau dia mau memasang iklan permintaan maaf di harian Kompas selama tujuh hari berturut-turut satu halaman penuh. Karena dia tidak tahu, dan baru tahu pada saat itu juga yang namanya UU ITE pasal 27 ayat 3, akhirnya dia ikut saja dan dipenjara kurungan lima bulan (Jono)."
\end{abstract}

Melalui kutipan di atas, hal ini menceritakan jika seorang mahasiswa, AY, sudah tidak memiliki privasi —yang berniat memceritakan kekesalan yang dialami selama menyewa kamar kos kepada temannya di Facebook; pihak lain (yaitu pemilik kos) yang notabene tidak berteman di Facebooknya, mengetahui postingan tersebut dan melaporkan ke kepolisian. Pun hal ini bisa dilihat, relasi kuasa yang dimiliki oleh pemilik kos sebagai 'pihak luar' yang meminta AY memasang iklan di halaman koran Kompas satu halaman penuh selama tujuh hari berturut-turut yang nilainya ratusan juta, bisa dikatakan 'sulit untuk dipenuhi' bagi seseorang mahasiswa.

Jono bercerita aktivitas yang dilakukan AY setelah keluar penjara, "AY menggunakan Facebooknya untuk memposting hal-hal yang lucu dan inspiratif dan aku tidak berani yang bersifat mengkritik." Kejadian tersebut memberikan dampak ketakutan, tidak hanya AY, tetapi juga kesadaran terhadap ketakutan oleh Jono dalam bermedia sosial, seperti dalam kutipan berikut:

"Pada saat kita meng-update status Twitter atau Facebook, kita merasa ada ketakutan tersendiri. Karena saya paham betul, bahwa kebanyakan sebagai barang bukti adalah screenshot/foto status di media sosial. Saya merasa tidak nyaman jika (bukti foto) tersebar secara publik."

Pengalaman tersebut menjadi pengalaman yang menakutan dalam diri, baik sebagai korban pelaporan UU ITE (AY) maupun Jono sebagai jurnalis yang paham betul atau secara sadar jika dirinya juga bisa menjadi 'calon korban' berikutnya karena status media sosial miliknya.

Meskipun merasa ketakutan dengan adanya ancaman dari UU ITE tersebut, Jono masih aktif bermedia sosial. Akan tetapi dengan siasat yang dilakukannya, yaitu bercuit (tweet) di akun Twitter miliknya yang tidak mengkritik orang lain dan lebih kepada Retweet (RT) akun yang inspiratif, mengomentari cuitan akun teman yang dia ikuti, dan bercuit tentang kehidupan pribadinya (keadaan apa yang dia rasakan, seperti suasana waktu di kereta atau cuaca pada siang hari di Jakarta). Hal yang sama ketika menggunakan Facebook, dia lebih meng-update status tentang berita inspiratif dan lebih kepada kehidupan personalnya. Ada lagi, ketika teman Facebook-nya membagi foto dengan men-tag atau menyebutkan username-nya, otomatis postingan tersebut muncul di laman (wall) Facebook miliknya. Dengan sadar, dia menghapus tag tersebut, karena dia merasa sensitif dan tidak ingin orang mengetahui lokasi atau keberadaan dirinya sedang di mana. Disinilah, kita melihat bagaimana Jono menyiasati untuk tidak 'berhadapan langsung' dengan pihak yang mungkin saja bisa berkonfrontasi atau tersinggung dengan status media sosialnya dan dilaporkan menggunakan UU ITE. Dia menyiasatinya dengan mengeliminir kemungkinan-kemungkinan untuk sekadar mengkritik atau mengomentari kritis akun lain.

Teknologi selalu terikat dengan pengguna. Hal ini berarti kemampuan untuk terhubung dan mengakses informasi selalu hadir untuk pengguna individu. McLuhan (1964) mengatakan jika medium sebagai ekstensi dari tubuh manusia. Misalnya kita bisa melihat gambar teman kita melalui akun media sosialnya dan mendengarkan videonya. Artinya smartphone kita menjadi perpanjangan dari organ tubuh mata dan telinga. Lupton (2006) menambahkan bagaimana sebagian besar orang memiliki hubungan sosial dan emosional dengan komputer, bahkan dapat menghabiskan waktu di depan layar komputer lebih lama dari pada bertatap muka dengan orang lain. Lebih lanjut, Lupton mengilustrasikan jika komputer sebagai manusia (lebih tepatnya menubuh/embodied). 
Di masa sekarang, telepon genggam menjadi alat yang sangat populer untuk berkomunikasi dan mencari hiburan dan kebanyakan mereka menggunakan internet untuk memenuhi kebutuhan online mereka (BCG Report, 2015). Alat (device) ini hampir selalu bersama kita dan teknologi selalu terikat dengan pengguna. Artinya kemampuan untuk terhubung dan mengakses informasi selalu hadir untuk pengguna individu (Calka, 2015:17). Penubuhan seperti yang digambarkan Lupton, beralih dan berganti menjadi telepon genggam (smartphone).

Dari uraian di atas, penubuhan di dunia siber menjadi sangat kompleks, karena tidak lagi menganggap smartphone dan media sosial sebagai benda mati dan sebatas media (teknologi) untuk memediasi atau mengomunikasikan hasil apa yang kita pikirkan. Meskipun tubuh telah terisolir dari 'tubuh yang asli' dan secara implisit terlihat mati (istilah yang tepat merujuk kepada "electronic cadaver" (mayat elektronik) (Paul, 2002)), tubuh di dunia siber seolah-olah hidup karena telah dipengaruhi oleh interaksi dan intervensi teknologi, relasi simbiotis antara manusia dan mesin (teknologi), dan budaya.

Melalui pembahasan penubuhan di dunia siber, hal tersebut menunjukkan akun media sosial tidak hanya sebagai representasi individu saja, melainkan hubungan yang mengikat dan mengintervensi pada relasi kultural dan teknologis dalam menempatkan individu, baik di dunia siber atau dunia 'nyata.' Akan tetapi keberadaan atau posisi dari tubuh di dunia siber memiliki permasalahan yang kompleks, yaitu bisa dikatakan 'privasi yang memudar' saat bermedia sosial.

\section{c. Pendisiplinan yang Terinternalisasi}

Berbeda dengan Jono, Ananda yang memiliki latar belakang sebagai mahasiswa hukum, ia bisa dikatakan lebih aktif dalam bermedia sosial. Ia menggunakan Facebook untuk membagi aktivitas kesehariannya atau membagi foto pribadinya saat di lokasi tertentu, selain itu juga, dia menggomentari berita dari website tertentu dan dengan komentar yang 'mencerahkan.' Sedangkan twitter, dia menggunakannya selain kedaan kesehariannya, status twitter saya berbentuk kultweet (Kuliah Tweet) tentang sebuah topik tertentu, kemudian bisanya saya copy-paste ke status Facebook. Rata-rata tentang hukum dan tentang politik dan sesuai dengan latar belakang perkuliahannya.

Meskipun demikian, Ananda yang memiliki latar belakang pendidikan di bidang hukum, dia merasakan ketakutan saat mem-posting sesuatu yang bernada kritik. Seperti yang diungkapkannya berikut:

"Kalau setelah dibentuknya UU ITE 27 ayat 3, sama kaitannya dengan KUHP Pasal 310 (tentang Pencemaran nama baik), UU ini melengkapi unsur-unsur elektroniknya. Jadi belum membatasi, tapi kelemahannya belum dijelaskan secara jelas kriteria atau kategori yang termasuk dalam pencemaran nama baik. Jadi kembali lagi, saya masih ada ketakutan untuk melakukan kritik terhadap seseorang. Biasanya saya tweet secara umum dan tidak memojokkan seseorang” (Ananda).

Petikan wawancara di atas menunjukkan jika Ananda masih memiliki rasa ketakutan dalam dirinya saat bermedia sosial, karena kategori yang belum jelas unsur apa yang termasuk pencemaran nama baik. Kesadaran tersebut tercermin saat dia menyiasati kritik melalui Twitter, akan tetapi kritik yang secara umum dan tidak memojokkan seseorang yang dia kritik. Dia juga tidak menggunakan kata-kata yang kasar dan kotor kepada seseorang, dan sesuai dengan fakta, bukan berpretendensi untuk memfitnah.

Hal yang menarik ketika saya menanyakan kepada Ananda apakah perlu pasal karet tersebut dihapuskan, dia menjawab dengan tegas, tidak. Aturan dalam UU ITE ini, terutama pasal 27 ayat 3 ini perlu, karena jika tidak ada aturan ini seseorang bisa seenaknya bercuit di Twitter tidak hanya melakukan kritik, tetapi juga bisa saja menggunakan kata-kata yang menyinggung Ras, menghina, atau melakukan fitnah kepada seseorang. Seperti misalnya akun kontroversial, akun Twitter anonim@Triomacan2000 yang setiap tweet-nya menyuarakan kebencian dan fitnah yang belum terbuki terhadap seseorang yang di-tweet-nya. Ananda bercerita, "karena akun anonim dan tim cybercrime baru dibentuk akhir-akhir ini, jadi bisa ditangkap dengan UU ITE." Menurut penelitian Rosenfeld bahwa usaha untuk melawan ujaran kebencian melalui hukum setidaknya dapat mengamankan kesopanan pengguna (Rosenfeld, 2001:63; Cammaerts, 2009:571).

Menurut penelitian Cammaerts (2009:570) menunjukkan bahwa hal terpenting dalam melihat kebebasan untuk berpendapat (freedom of speech) tidak hanya bersikap pesismis mengenai peran negara terhadap penyensoran ujaran kebencian ini yang dianggap membatasi kebebasan masyarakat, akan tetapi lebih kepada kewaspadaan kita terhadap kesulitan yang dihadapi melawan ujaran kebencian ini melalui ukuran secara legal (hukum) dan konsekuensi dari praktik yang dilakukan. Kemudian pertanyaan akan muncul: siapa yang mendefinisikan ujaran itu menyakitkan, ofensif, melukai, atau merugikan dan konteks apa yang digunakan dalam bahasa tersebut?.

Ananda juga merasakan hal yang serupa dengan Cammaerts, ketika definisi yang dimaksudkan dalam pencemaran nama baik dalam UU ITE pasal 27 ayat 3 ini belum jelas, jadi masih bersifat multitafsir dan sangat berbahaya jika begitu. Ananda lebih memilih untuk bernegosiasi dengan penjelasan kategori yang jelas dalam pasal 27 ayat 3 perbuatan atau unsur apa yang termasuk dalam kategori pencemaran nama baik, dari pada menuntut untuk menghapuskan pasal ini. Karena jika pasal ini dihapuskan, justru yang terjadi akan semakin bebas, dan banyak status yang menyuarakan kebencian tanpa disensor dan menggunakan kata-kata kasar. 
Hadirnya UU ITE ini tidak bisa dihindarkan dari gerakan protes pengguna media sosial di seluruh Indonesia. Terutamanya pada pasal pencemaran nama baik yang mengundang reaksi keras dari netizen yang merasa kebebasan berpendapatnya di media sosial terbatasi dan meresahkan dengan berbagai 'korban' yang dilaporkan menggunakan UU ITE pasal 27 ayat 3. Seperti yang terjadi saat Foucault menggambarkan keadaan cahaya yang menerangi sel penjara, artinya tahanan tidak dapat melihat ke dalam tower penjaga, tapi penjaga dapat melihat keadaan di dalam sel penjara. Tahanan tidak pernah tahu apakah dia diawasi atau tidak. Oleh karena itu, tahanan harus memonitor perilaku mereka sendiri seolah-olah mereka sedang diawasi. Sehingga disiplin menjadi terinternalisasi (Bell, 2001: 82-83). Efek mayor dari panoptikon adalah merangsang keadaan sadar tahanan dan pandangannya yang meyakini fungsi otomatis kekuasaan, sehingga efek permanen dari panoptikon ini berlangsung; aparatus arsitektural (menara penjaga) sebagai mesin untuk menciptakan dan memelihara relasi kekuasaan (Foucault, 1995: 201).

Analoginya seperti yang digambarkan oleh Foucault tentang pendisiplinan tower penjaga di penjara. Tower penjaga seperti halnya dengan UU ITE sebagai alat untuk mengawasi 'calon korban.' Ada atau tidak adanya penjaga/sipir penjara dalam tower, seperti dengan sepasang mata yang kapan saja dapat membaca status akun media sosial, inilah yang memerankan fungsi pengawasan. Meskipun pengguna media sosial sedang tidak diawasi secara langsung, pengawasan ini terinternalisasi oleh masing-masing individu pengguna media sosial untuk mendisiplinkan diri melalui tubuh siber (cyber body).

\section{KESIMPULAN}

Artikel ini telah mengkaji pergolakan bermedia sosial karena hadirnya UU ITE (terutama pasal 27 ayat 3) membatasi kebebasan berpendapat dalam bermedia sosial untuk melayangkan kritiknya sebagai audiens yang sekaligus sebagai produsen aktif menyampaikan pendapatnya. Hal ini menjadi ironi, ketika media sosial digadang-gadang menjadi ruang untuk bebas berpendapat, tetapi juga bisa menjadi ruang yang membuat seseorang dipenjara. Persoalan privasi dan penubuhan di dunia siber juga dibahas bagaimana pada saat bermedia sosial, privasi menjadi memudar dan penubuhan di dunia siber tidak hanya sebagai representasi penggunanya, tetapi juga mengintervensi dan mengikat pada relasi individu, budaya, dan teknologi. Demikianlah artikel yang mengajak memahami pergolakan bermedia sosial di bawah bayangbayang UU ITE, terutama pasal 27 ayat 3 melalui berbagai perspektif yang berbeda untuk menambah kekayaan dalam memahami kompleksitas persoalan ini.

\section{DAFTAR PUSTAKA}

Balea, Judith. (2016). The latest stats in web and mobile in Indonesia (INFOGRAPHIC). Techinasia. Internet. (https:// www.techinasia.com /indonesia-web-mobile- statistics-we-are-social). Diakses pada tanggal 26 Mei 2017.

BCG Report. (2010). The Internet's New Billion: Digital Consumers in Brazil, Russia, India, China, and Indonesia, Boston: The Boston Consulting Group.

Bell, D. (2001). An Introduction to Cybercultures, London: Routledge.

Calka, Michelle. (2015). "Polymediation: The Relationship between Self and Media." Dalam Beyond New Media: Discourse and Critique in a Polymediated Age. Diedit oleh Art Herbig, Andrew F. Hermann, dan Adam W. Tyma, London: Lexington Books.

Cammaerts, Bart. (2009). "Radical pluralism and free speech in online public spaces: The case of North Belgian extreme right discourses." International Journal of Cultural Studies, 12(6): 555-575.

Dahlgren, P. (2013). "From public to civic intellectuals via online cultures". Journal of Audience and Reception Studies, 10(1):400-404.

Foucault, M. (1995). Discipline and Punish: The Birth of the Prison. Edisi Kedua. Diterjemahkan oleh Alan Sheridan, New York: Vintage Books.

. (1978). The History of Sexuality. Diterjemahkan oleh Robert Hurley, New York: Pantheon Books.

Hukum Online. (2015). Vonis Penjara Untuk Tiga Admin Trio Macan. Hukum Online. Internet. (http://www.hukumonline. com/berita/baca/lt55a5fef3dac33/vonis-penjara-untuk-tiga-admin-trio-macan). Diakses pada tanggal 26 Mei 2017. (https://www.bcg.com/documents/file58645.pdf). Diunduh pada tanggal 25 Mei 2017.

(2017). Ini Cara Ahli Cyber Crime Melacak Admin Akun Anonim Medsos. Hukum Online. Internet. (http://www.hukumonline.com/berita/baca/lt551b98e8a661f/ ini-cara-ahli-cyber-crime-melacak-admin-akunanonim-medsos). Diakses pada tanggal 26 Mei 2017.

Kominfo. (2014). Pengguna Internet Indonesia Nomor Enam Dunia. Kominfo. Internet. (https://kominfo.go.id/content/ detail/4286/pengguna-internet-in donesia-nomor-enam-dunia/0/sorotan_media). Diakses pada tanggal 26 Mei 2017. 
(2016). Undang-Undang Informasi dan Transaksi Elektronik No. 11 Tahun 2008, Jakarta: Kementrian Komunikasi dan Informasi. (http://www.anri.go.id/assets/download/97UU-Nomor-11-Tahun-2008-TentangInformasi-dan-Transaksi-Elektronik.pdf). Diakses pada tanggal 25 April 2017.

Kurniawan, N. I. (2001). "Melacak Pemikiran Anthony Giddens Tentang Nation-State dan Modernitas." Jurnal Ilmu Sosial dan Ilmu Politik,4(3):341-364.

Lubis, C. (2016). Memprotes Revisi UU ITE. MetroTv News. Internet. (http://metrotvnews.com/welcome-page/ news/8Kyd5ZEk-memprotes-revisi-uu-ite). Diakses pada tanggal 28 Mei 2017.

Lupton, D. (2006). "The embodied computer/user." Dalam Cybercultures: Critical Concepts in Media and Cultural Studies. Diedit oleh David Bell. USA: Routledge.

McLuhan, Marshall. (1964). Understanding Media: The Extension of Man, London: Routledge.

Morse, M. (2006). "What Do Cyborgs Eat? Oral Logic in an Information Society." Dalam Cybercultures: Critical Concepts in Media and Cultural Studies. Volume IV. Diedit oleh David Bell. USA: Routledge.

Mozes, A. (2014). Kena Vonis 6 Bulan, Benhan: Tak Bebas Lagi Mengkritik Pejabat Publik. Tribun News. Internet. (http://www.tribunnews.com/nasional/2014/02/05/kena-vonis-6-bulan-benhan-tak-bebas-lagi-mengkritikpejabat-publik). Diakses pada tanggal 28 Mei 2017.

Panji, A. (2012). “Change.org, Media Sosial untuk Perubahan Sosial.” Kompas. Diakses pada tanggal 16 Januari 2018. (http://tekno.kompas.com/read/2012/10/15/ 10090221/Change.org..Media.Sosial.untuk.Perubahan.Sosial).

Paul, C. (2002). “Cyborg as Cyberbody.” Art History Department. New YorkL School of VIsual Art. (http://ekac.org/ artlab23,html). Diakses pada tanggal 29 Mei 2017.

PAKU ITE. (2013-2017). \#Gara2UUITE, pengguna media sosial bisa dipenjara. Change.org. Internet. (https://www. change.org/m/gara2uuite-pengguna-media-sosial-bisa-dipenjara). Diakses pada tanggal 29 Mei 2017.

Rakhmansyah, Rizky. (2017). Betapa Tidak Pedulinya Orang Indonesia Karena Media Sosial. Mahasiswa bicara. Internet (https://mahasiswabicara.id/viral /2017/04/betapa-tidak-pedulinya-orang-indonesia-karena-media-sosial/). Diakses pada tanggal 26 Mei 2017.

Ritzer, George. (2013). "Prosumption: Evolution, revolution, or eternal return of the same?" Journal of Consumer Culture, 1-22. Penerbit Sage Publications.

Safenet Voice. (2017). Daftar Kasus Netizen yang Terjerat UU ITE, Online: Safenet Voice. (http://safenetvoice.org). Diunduh pada tanggal 11 Maret 2017.

Saukko, Paula. (2003). Doing Research in Cultural Studies: An Introduction to Classical and New Methodological Approaches, London: SAGE Publications Ltd.

Sugiharto, B. A. (2016). 'Pasal Karet' UU ITE Jadi Pamungkas Jeratan Hukum. CNN Indonesia. Internet. (http://www. cnnindonesia.com/teknologi/20161228182458-185-182719/pasal-karet-uu-ite-jadi-pamungkas-jeratan-hukum/). Diakses pada tanggal 27 Mei 2017.

Toffler, Alvin. (1980). The Third Wave, New York: Bantam Books.

Undang-Undang Republik Indonesia tentang Informasi dan Transaksi Elektronik. Nomor 11 Tahun 2008. Diakses pada tanggal 31 Desember 2017. (http://www.dpr.go.id/dokjdih/document/uu/UU_2008_11.pdf).

Walton, D. (2008). Introducing Cultural Studies: Learning through Practice, London: SAGE Publications Ltd.

Widiantoro, W. (2011). Lima Korban “Pasal Karet” UU ITE. Tekno Kompas. Internet. (http://tekno.kompas.com/ read/2015/01/30/16170037/Lima.Korban.Pasal.Karet.UU.ITE). Diakses pada tanggal 28 Mei 2017.

Yanuar. (2015). Ervani Terdakwa Pencemaran Nama Baik via Facebook Divonis Bebas. Liputan 6. Internet. (http://news. liputan6.com/read/2156308/ervani-terdakwa-pencemaran-nama-baik-via-facebook-divonis-bebas). Diakses pada tanggal 28 Mei 2017.

\section{Wawancara:}

Ananda. Wawancara dilakukan pada tanggal 7 April 2017.

Jono. Wawancara dilakukan pada tanggal 2 Maret 2017. 
